\title{
PERBAIKAN MUTU RANSUM SAPI POTONG MELALUI PEMBERIAN KONSENTRAT BERBASIS PAKAN LOKAL DI PURWAKARTA
}

\author{
Iman Hernaman, Atun Budiman, Ana Rochana Tarmidi \\ Fakultas Peternakan, Universitas Padjadjaran \\ E-mail: iman_hernaman@yahoo.com
}

\begin{abstract}
ABSTRAK. Purwakarta merupakan kabupaten di Jawa Barat yang memiliki posisi strategis sebagai pusat peternakan, selain pertanian dan industri. Di sektor peternakan khususnya sapi potong menunjukan kinerja yang baik. Hal ini dari meningkatnya populasi sapi potong dan kerbau berdasarkan sensus pertanian Tahun 2013 sebesar 7,34\%. Dari sisi pemasaran sapi potong tidaklah sulit karena daerah ini dekat dengan ibukota Jakarta dan memiliki jaringan transportasi terutama jalan Tol yang baik, sehingga memudahkan dalam distribusi penjualan sapi potong ke Jakarta. Namun para peternak sapi potong belum memberikan ternaknya ransum yang berkualitas, mereka hanya mengandalkan hijauan alam yang memiliki kualitas rendah. Pemberian konsentrat sebagai makanan tambahan akan memberikan solusi untuk meningkatkan performa sapi potong. Melalui kursus singkat diharapkan peternak dapat memformulasikan konsentrat berbahan baku lokal melalui serangkaian kegiatan PKM yang terdiri dari : (1) Persiapan berupa observasi daerah sasaran dan menghimpun kepustakaan yang relevan, (2) Pelatihan pengenalan pengetahuan bahan pakan, kebutuhan nutrien sapi potong dan penyusunan konsentrat menggunakan program Excell 3) Demonstrasi plot pelatihan pencampuran konsentrat dengan metode manual, dan produksi konsentrat yang akan diujicobakan ke sapi potong milik peternak.4) Evaluasi dilakukan setelah proses pelatihan dan demonstrasi plot. Hasil kegiatan menunjukkan bahwa peternak memiliki ketertarikan dalam kegiatan ini dengan indikator banyaknya yang datang dan berperan aktif dala ,m penyuluhan maupuan demonstrasi plot, mereka mampu mengoperasikan program formulasi dari Excell. Formulasi ransum akan efektif bila dilaksanakan secara terbatas bagi peternak yang memiliki kemampuan mengoperasikan program Excell. Perlu pembuktian hasil pelatihan formulasi konsentrat dengan menerapkan konsentrat hasil formulasi berbahan baku lokal dengan melakukan aplikasi pada ternak sapinya.
\end{abstract}

Kata kunci: ransum, sapi potong, sentra peternakan rakyat

\section{THE MUTUAL IMPROVEMENT OF BEEF CATTLE DIETS THROUGH FEEDING LOCAL FEED CONCENTRATE AT PURWAKARTA REGENCY}

\begin{abstract}
Purwakarta is one of regencies in West Java which has a strategic position as centre of farming and industries. Livestock sectors, in particular to beef cattle have shown a good performance. This can be seen from the increase of beef cattle and buffalo populations at 7.34\% based on census in 2013. The Markets of beef cattle in Purwakarta is hugely opened as its location is near to the Capital Province of Jakarta and is supported by a highway 'Tol' road that making the distribution easier. Nonetheless, the update condition shows that most farmers in Purwakarta are not feeding their cattle with a standard quality of diets. They are just depending upon low quality roughages. Feeding concentrate as an additional diet can be the solution to improve the cattle performances. Thus, a number of short trainings about how to formulate concentrate diet using local feed ingredients has been done for the farmers included: (1) preparation to choose a targeted location for the training and obtaining relevant references, (2) training consisted of introduction to feed raw materials, beef cattle nutrient requirements, and concentrate formulation using Excell, (3) field demontration as follows: training on how to mix concentrate manually, concentrate production, and testing to feed the concentrate to the farmer's cattle, and (4) Evaluation after training and field demontration. The result of activity showed that farmers had interest in this training and can be seen from the high number of participants and they were also active both in the class and field demonstration and they can operat excell program to formulate diets of beef cattle effectively. It is needed to prove the outcomes of the training on concentrate formulation using local feed materials to be applied in their places for their cattle.
\end{abstract}

Keywords: ration, beef cattle, centre of farmer community

\section{PENDAHULUAN}

Purwakarta adalah salah satu kabupaten/kota yang mendapatkan prioritas sebagai tempat kegiatan Sentra Peternakan Rakyat (SPR) dari 50 SPR yang menjadi pilihan dari Direktorat Jenderal Peternakan dan Kesehatan hewan dengan komoditas ungulan sapi potong. Hal ini dimungkinkan karena perkembangan sapi potong yang tercatat cukup signifikan yang dilihat dari hasil sensus pertanian pada tahun 2013 terjadi kenaikan jumlah sapi potong dan kerbau sebesar 7,34\%. Selain itu, Purwakarta sebagai kabupaten penyangga Ibukota Negara memiliki posisi strategis sebagai pemasok kebutuhan daging bagi penduduk Jakarta, akses jalan tol yang melintas Purwakarta memudahkan dalam distribusi ternak ke wilayah tersebut.

Namun secara umum peternak di wilayah SPR masih melakukan budidaya ternak secara tradisional. Kebutuhan ransumnya mengandalkan hijauan dari alam sekitarnya yang memiliki kualitas yang rendah karena tidak pernah mengalami pemupukan dan jarang memperhatikan umur dari hijauan tersebut yang sangat berpengaruh terhadap kualitas hijauan pakan. Saat ini mereka jarang menggunakan pakan tambahan berupa 
konsentrat karena dianggapnya bahan tersebut harus dibeli dan akan menambah biaya usahapeternakannya. Hal ini mengakibatkan ternaknya memiliki performan yang tidak sesuai dengan potensi genetiknya.

Konsentrat adalah pakan yang kaya akan sumber protein dan atau sumber energi, serta dapat mengandung pelengkap pakan dan atau imbuhan pakan (Keputusan Menteri Pertanian Nomor: 242/Kpts/OT.210/4/2003). Hasil survai menunjukkan banyak ternak sapi yang tidak sesuai dengan potensi genetiknya, hal ini tampak dari bobot sapi yang relative lebih rendah daripada semestinya. Anggapan bahwa pemberian konsentrat tidak menguntungkan tidaklah benar karena jika diberikan konsentrat akan menghasilkan pertambahan bobot badan yang tinggi dan menghasilkan keuntungan yang lebih besar daripada biaya konsentrat yang diberikan. Konsentrat juga dapat menentukan kapan saatnya ternak itu harus dijual atau dipotong, sehingga peternak akan lebih efektif dalam perencanaan waktu.

Pembuatan konsentrat akan mahal jika semua komponen bahan baku pakan diperoleh dari luar kawasan tersebut, serta konsentrat tidak akan memberikan hasil yang baik jika tidak dikomposisi secara benar. Potensi bahan pakan di daerah tersebut sebenarnya cukup melimpah diantaranya jagung, dedak padi, dan singkong. Bahan bahan tersebut jika dicampur ditambah dengan legume sebagai sumber protein akan menjadi sumber konsentrat yang dapat digunakan sebagai bahan pakan tambahan untuk meningkatkan performa sapi potong.

Dalam pembuatan konsentrat tentunya tidaklah mudah, membutuhkan pengetahuan tentang sifat, dan kualitas bahan baku pakan serta kemampuan untuk menyusunnya. Teknik menyusun ransum/konsentrat telah banyak dilakukan diantaranya dengan mengunakan perhitungan secara manual, namun kelemahannya adalah lama, dan belum tentu menghasilkan formula yang sesuai dengan kehendak.Untuk mendapatkan pengetahuan tersebut dibutuhkan transfer pengetahuan dan teknologi melalui kegiatan penyuluhan dan demonstrasi plot. Penyuluhan sangat memiliki peranan penting dalam pengembangan peternakan khususnya dalam penguatan kelompok tani dan peningkatan proses adopsi teknologi peternakan kepada peternak (Abdullah, 2008). Penyuluhan dilanjutkan dengan demonstrasi plot yang diharapkan peternak dapat melakukannya, demonstrasi plot sangat efektif dalam meningkatkan keteramplan dan pengetahuan petani (Hindersah, dkk., 2016)

Penggunaan program formulasi berbasis Excell relative mudah diaplikasikan. Kemampuan yang terakhir ini tentunya hanya dimiliki oleh masyarakat yang memiliki keamampuan intelektual yang baik, namun demikian diantara peternak ada beberapa diantaranya berpendidikan minimal SMA atau memanfaatkan anaknya yang rata-rata berpendidikan SMA sebagai sasaran pelatihan pembuatan formualsi ransum/konsentrat.

\section{METODE}

Kerangka pemecahan dalam bentuk kursus singkat yang dilakukan meliputi beberapa tahapan pelaksanaan kegiatan yaitu:

1. Persiapan

a. Observasi daerah sasaran dengan melakukan konfirmasi dengan berbagai pihak terutama peternak tentang tatacara pemberian ransum pada ternaknya serta bagaimana potensi bahan pakan yang ada di sekitar mereka, apakah sudah digunakan, apakah ada kendala dari penggunaan bahan pakan tersebut.

b. Memilih dan menghimpun kepustakaan yang relevan untuk memecahkan persoalan yang terjadi di masyarakat tersebut.

2. Pelatihan

Kegiatan pelatihan dilakukan secara kelompok dengan cara tatap muka bersama peserta, membagi brosur, ceramah, dilanjutkan dengan diskusi. Pelatihan ini dibagi ke dalam beberapa tahap, yaitu

a. Pelatihan mengenai pengetahuan bahan pakan

c. Dalam pelatihan ini peternak akan diberikan contoh bahan pakan, karakteristikya yang terkait dengan penggunaannya

d. Pelatihan mengenai kebutuhan nutrien sapi potong

e. Materi yang disampaikan berupa pentingnya nutrien yang terkait dengan pertumbuhan dan perkembangan sapi potong sesuai dengan tujuan produksi atau fase kehidupannya.

f. Pelatihan Penyusunan Konsentrat

g. Khusus untuk pelatihan penyusunan konsentrat dilakukan dengan cara melatih ketua kelompok atau anggota yang menguasi komputer.

3. Demonstrasi Plot

Demonstrasi plot dilakukan setelah proses pelatihan penyusunan konsentrat selesai dilaksanakan. Demonstrasi plot yang dilakukan adalah pelatihan pencampuran konsentrat dengan metode manual.

4. Evaluasi

Tahap evaluasi ini dilakukan setelah proses pelatihan dan demonstrasi plot melalui tingkat pemahaman dari pelatihan tersebut.

\section{HASIL DAN PEMBAHASAN}

Pada tahap pertama dilakukan observasi lapangan untuk mengetahui sejauhmana potensi peternakan yang dimiliki oleh daerah sasaran. Observasi lapangan dilakukan melalui pertemuan dengan pihak Kepala Bidang Peternakan Dinas Perikanan dan Perternakan Kabupaten Purwakarta dan survai ke lokasi target sasaran kegiatan pengabdian pada masyarakat. Dari 
hasil observasi lapangan yang dilaksanakan pada bulan Mei 2016, terungkap bahwa profil daerah sasaran merupakan kawasan perbukitan dengan masyarakat sebagian besar bercocok tanam, dan banyak memelihara sapi potong yang sebagian digembalakan di lahanlahan terbuka terutama lahan milik negara. Selama ini pemberian pakan yang dilakukan untuk peternak adalah memanfaatkan hijauan lapangan yang ada disekitar mereka baik melalui penggembalaan atau menyabit rumput. Beberapa peternak sudah melakukan pemberian pakan tambahan melalui pemberian dedak padi, namun kenyataannya mereka tidak menghasilkan sapi potong yang maksimal performannya. Pemberian pakan tambahan berupa konsentrat sangat dibutuhkan dalam rangka memaksimalkan usaha ternaknya. Akan tetapi pengetahuan mereka tentang pembuatan konsentrat sangat rendah bahkan kebanyakan tidak sama sekali. Hal ini yang menjadi alasan perlunya penyuluhan formulasi konsentrat dan praktek cara melakukan pencampuran bahan pakan menjadi konsentrat.

Tahap berikutnya adalah penyuluhan yang dilaksanakan di Balai Desa Tegal Waru pada tanggal 22 Juli 2016, yang dihadiri oleh kepala desa, aparat desa dan Perwakilan dari Dinas Perikanan dan Peternakan Kabupaten Purwakarta serta peternak sebanyak 45 orang.Penyuluhan ini merupakan bagian dari motivasi pada peternak bahwa pemberian konsentrat memiliki dampak yang sangat positive bagi peningkatan performa pada sapi potong. Disamping itu dijelaskan pula bahwa banyak potensi bahan pakan lokal yang dapat dijadikan sebagai bahan baku pembuatan konsentrat. Pada kesempatan ini dilakukan demplot formulasi konsentrat untuk membuktikan bahwa membuat formulasi dapat dilakukan dengan cepat dan mudah. Pada hakekatnya penyuluhan merupakan salah satu sarana untuk membantu masyarakat desa mencapai kehidupan yang lebih layak, khususnya melalui pemanfaatan hasil hasil penelitian dan perealisasian kebijakan pembangunan pertanian (Van den Ban dan Hawkins, 1999). Melalui penyuluhan diharapkan adanya perubahan perilaku dari masyarakat.

Demonstrasi yaitu menunjukkan, membuktikan atau meragakan sesuatu yang nyata agar orang lain mempercayainya (Mardikanto, 1993). Metode demonstrasi yang dilaksanakan pada tahap awal yaitu Demplot (Demonstrasi plot). Demonstrasi plot dilaksanakan setelah kegiatan penyuluhan berlangsung. Praktek ini penting karena membutuhkan keahlian tertentu agar mereka dapat mencampur dengan baik, terutama bagaimana mencampur bahan baku pakan dengan jumlah yang kecil. Peserta berperan aktif dalam kegiatan dengan menyimak dan melaksanakan langsung kegiatan demonstrasi plot mencampur ransum yang berlangsung di halaman balai desa. Beberapa pertanyaan pada kesempatan ini dilontarkan terutama terkait dengan potensi bahan pakan lokal sebagai bahan baku pembuatan konsentrat. Tahap selanjutnya adalah penyuluhan dan demonstrasi plot dimana peserta diperluas, kelompok lain di lingkungan SPR dan para penyuluh peternakan diundang yang semuanya dimobilisasi oleh pihan Dinas Perikanan dan Peternakan Kabupaten Purwakarta. Peserta dalam hal ini adalah mereka yang memiliki kemampuan dalam mengoperasikan computer terutama program Excell. Peserta yang berasal dari pengurus SPR, yaitu anggota GPPT(Gugus Perwakilan Pemilik Ternak) dan perwakilan dari dinas terkait. Kegiatan ini dilaksanakan pada tanggal 24 September 2016 di salah satu rumah peternak andalan yang sekaligus juga anggota GPPT. Peserta sebelumnya diminta membawa LEPTOP sebagai perangkat yang digunakan untuk praktek formulasi konsentrat yang menggunakan program Excell. Peserta sebagian besar adalah peserta baru yang merupakan perwakilan dari para ketua dan pengurus kelompok. Kegiatan ini dihadiri oleh 24 peserta.

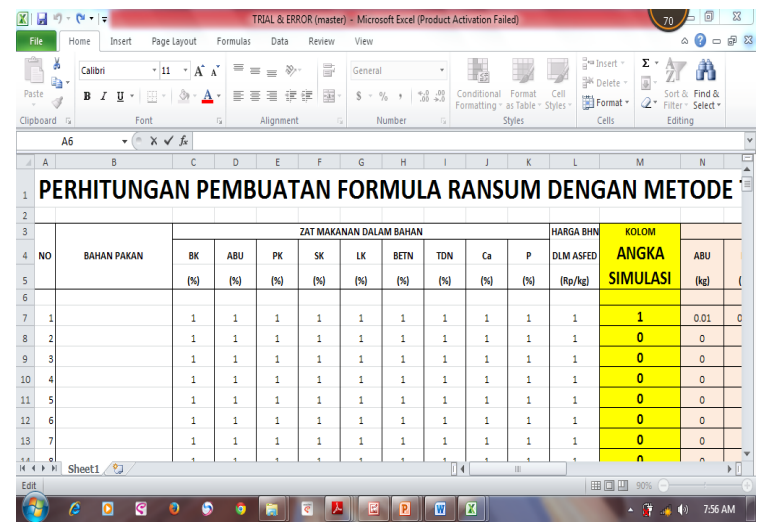

Gambar 1. Materi Penyusunan Konsentrat dalam Penyuluhan

Pada pelaksanaan praktek formulasi tampak peserta sangat antusias terutama para penyuluh yang menanyakan banyak hal terkait dengan formulasi konsentrat. Kegiatan penyuluhan ini diawali dengan pemaparanmenenai makna nutrisi untuk ternak, istilah-istilah dalam menyusun konsentrat dan pengertian serta syarat yang harus dipenuhi dalam formulasi konsentrat. Dalam penyuluhan ini ada beberapa peserta yang bertanya diantaranya :

1. Pengertian probiotik dan prebiotik?

2. Syarat membuat konsentrat sapi potong?

3. Bisa tidak program ini digunakan untuk ternak jenis yang lain?

Selanjutnya pada hari yang sama dilakukan demontrasi plot bagaimana cara mencampur bahan baku konsen-trat menjadi konsentrat. Tahap yang dilakukan dalam praktek ini adalah dimulai dengan mencampur bahan yang kecil dengan bahan yang kecil dalam formulasinya, lalu dicampur lagi dengan bahan yang lain yang lebih besar dengan bahan yang sebelumnya dicampur, dan begitu seterusnya. Dalam kesempatan demonstrasi plot ini peserta dibagi ke dalam dua kelompok agar lebih focus dalam prakteknya.Pada pelaksanaan kegiatan praktek ini 


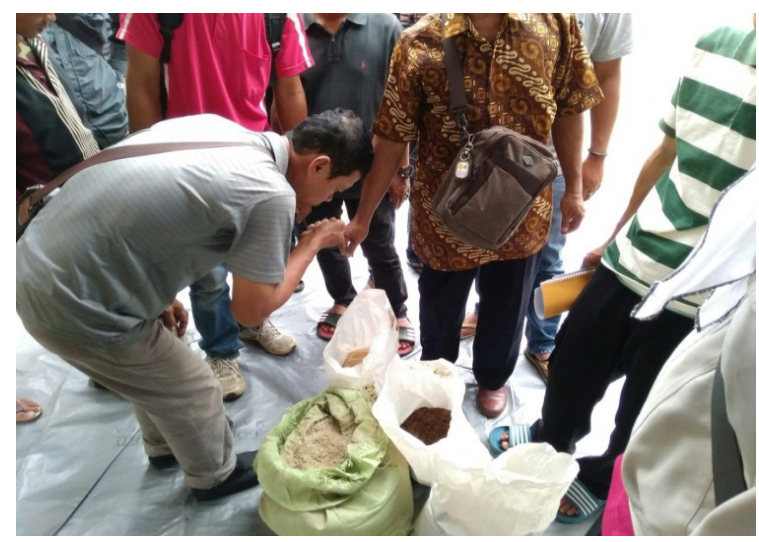

Gambar 2. Kegiatan Peserta dalam Pelaksanaan Demonstrasi Plot

peserta antusias dalam melaksanakan praktek terlihat dari banyaknya peserta yang terlibat. Beberapa pertanyaan yang dilontarkan terkait asal dari bahan pakan yang dibuat dalam praktek pembuatan konsentrat.

Tahap akhir adalah tahap evaluasi, dimana pada tahap ini peserta yang telah mengikuti penyuluhan dan demondtrasi plot berkumpul dan dievaluasi terkait dengan pelaksanaan kegiatan sebelumnya. Secara umum peserta mengerti cara melakukan formulasi ransum menggunakan program Excell, namun untuk membuat konsentrat belum sebagian besar dari mereka melaksanakan, namun mereka berjanji akan menerapkannya bila ada kesempatan dan modal yang akan datang. Evaluasi dilaksanakan pada tanggal 8 Oktober 2016 yang dihadiri oleh 39 peserta yang terdiri atas Manajer SPR, pengurus SPR dan perwakilan dari dinas. Lokasinya di Kelompok Tani Sapi Potong Tani Makmur Jaya.

Tabel 1. Perubahan Perilaku Peserta Selama dan Sesudah Kegiatan PMM Integratif

\begin{tabular}{|c|c|c|c|}
\hline No & Indikator & $\begin{array}{l}\text { Base Line } \\
\text { (sebelum } \\
\text { kegiatan) }\end{array}$ & $\begin{array}{c}\text { Pencapaian } \\
\text { Setelah Kegiatan }\end{array}$ \\
\hline 1 & Pengetahuan & $\begin{array}{l}\text { Tidak tahu } \\
\text { tentang formulasi } \\
\text { konsentrat }\end{array}$ & $\begin{array}{l}\text { Tahu tentang } \\
\text { formulasi } \\
\text { konsentrat }\end{array}$ \\
\hline 2 & Keterampilan & $\begin{array}{l}\text { Tidak terampil } \\
\text { dalam formulasi } \\
\text { dengan } \\
\text { menggunakan } \\
\text { Excell dan } \\
\text { mencampur bahan } \\
\text { baku menjadi } \\
\text { konsentrat }\end{array}$ & $\begin{array}{l}\text { Terampil dalam } \\
\text { formulasi dengan } \\
\text { menggunakan } \\
\text { Excell mencampur } \\
\text { bahan baku } \\
\text { menjadi konsentrat }\end{array}$ \\
\hline
\end{tabular}

Dari hasil evaluasi tersebut terdapat perubahan perilaku peserta yang disajikan pada Tabel 1. Secara umum peserta mengetahui tentang formulasi konsentrat juga dari keterampilan dalam mengoperasikan program formulasi dalam Excell. Hal ini menunjukkan bahwa para peternak sangat antusias dalam mengikuti program pengabdian pada masayarakat. Perubahan sikap ini terjadi akibat kemauan belajar dari peternak yang menginginkan adanya perubahan. Sikap dapat ditumbuhkan dan dikembangkan melalui proses belajar. Dalam proses belajar tidak terlepas dari proses komunikasi dimana terjadi proses tranfer pengetahuan dan nilai (Suharyat, 2017).Adopsi inovasi merupakan suatu proses mental atau perubahan perilaku baik yang berupa pengetahuan (cognitive), sikap (affective), maupun keterampilan (psychomotor) pada diri seseorang sejak ia mengenal inovasi sampai memutuskan untuk mengadopsinya setelah menerima inovasi (Rogers dan Shoemaker, 1971).

Untuk mencapai keberhasilan suatu kegiatan terdapat beberapa faktor yang saling berlawanan yaitu faktor pendorong dan penghambat. Dalam kegiatan pengabdian pada masyarakat terdapat beberapa faktor yang sangat membantu sehingga dapat terlaksanannya kegiatan ini yaitu :

1. Adanya dukungan dari aparat desa terutama peranan dinas terkait, pengurus SPR, aparat desa yang sangat membantu dalam menunjang kegiatan ini, begitu pula tokoh masyarakat, kelompok peternak, dan peternak yang turut pula memberikan pengaruhnya kepada masyarakat agar dapat hadir dalam penyuluhan ini.

2. Keingintahuan peternak dan masyarakat yang cukup tinggi, akibat kehadiran Sentra Peternakan Rakyat Kahuripan.

3. Banyaknya bahan pakan lokal sebagai penyusun konsentrat yang merupakan potensi yang belum tergali dengan baik.

4. Sudah terbentuknya kelompok petani atau peternak.

Meskipun dalam pelaksanaan kegiatan pengabdian masyarakat berjalan lancar, namun masih ditemukan faktor-faktor penghambat diantaranya:

1. Rendahnya tingkat pengetahuan dan pendidikan peternak untuk menerapkan informasi yang telah disampaikan dalam tindakan nyata.

2. Usahaternak masih merupakan usaha sambilan sehingga perhatian lebih banyak pada sektor lain terutama pertanian.

3. Keterampilan peternak dalam mengoperasikan komputer, sehingga hanya orang-orang tertentu saja yang bisa melakukan formulasi.

Faktor penghambat di atas dapat diatasi melalui kader yang didik, khusus. Dalam kegiatan ini peserta kegiatan selain peternak juga anak-anak mereka yang berpendidikan SMA, dimana mereka telah paham mengoperasikan computer. Kader tersebut diharapkan dapat melakukan formulasi dan dapat mentransferkan pengetahuan kepada kader yang lainnya yang memahami computer. Peningkatan pengetahuan pada kader diharapkan dapat mentransfer pengetahuannya untuk mencapai peningkatan kualitas hidup masyarakat (Hidayat, dkk., 2016). 


\section{SIMPULAN}

Telah dilaksanakan penyuluhan dan demonstrasi plot pada tahap pertama dan kedua dengan melibatkan peternak 45 dan 24 orang berikut aparat desa dan kepala desa; Peternak menunjukan ketertarikan dalam kegiatan ini dengan indikator banyaknya yang datang dan berperan aktiv dalam penyuluhan maupun demonstrasi plot serta mereka mampu mengoperasikan program formulasi dari Excell.

\section{DAFTAR PUSTAKA}

Abdullah, A. (2008). Peranan penyuluhan dan kelompok tani ternak untuk meningkatkan adopsi teknologi dalam peternakan sapi potong. Prosiding Seminar Nasionat Sapi Potong - Palu, 24 November 2008. Hal. 188195

Hidayat, W., Nur'aeny, N. dan Wahyuni, I.S. (2016). Pembekalan pengetahuan dan kemandirian dalam perawatan kesehatan gigi dan mulut masyarakat desa balingbing dan desa cidadap, kecamatan pagaden barat, Subang. Dharmakarya: Jurnal Aplikasi Ipteks untuk Masyarakat. Vol. 5, No. 1 : 34 - 37

Hindersah, R., Hermawan, W., Mutiarawati, T., Kuswaryan, S., Kalay, A.M., Talahaturuson, A. dan Risamasu, R. (2016). Penggunaan demonstrasi plot untuk mengubah metode aplikasi pupuk organik pada lahan pertanian sayuran di kota ambon. Dharmakarya: Jurnal Aplikasi Ipteks untuk Masyarakat. Vol. 5, No. 1 : 9 - 15

Mardikanto, T. (1993). Penyuluhan Pembangunan Pertanian. Sebelas Maret University Press. Surakarta

Roger, E.M. and F.F. Shoemaker. (1971). Communication of Innovation: A Cross Cultural Approach. The Free Press. New York

Suharyat, Y. 2017. Hubungan antara sikap, minat dan perilaku manusia. ejournal-unisma.net/ ojs/index.php/region/article/download/22/20. Diakses 26 November 2017.

Van Den Ban. A.W. dan H.S Hawkins. (1999). Penyuluhan Pertanian. Kanisius. Yogyakarta. 